\title{
Isolation of a Yeast Artificial Chromosome Contig Spanning the Greig Cephalopolysyndactyly Syndrome (GCPS) Gene Region
}

\author{
A. Vortkamp, M. Gessler, D. Le Paslier, * R. Elaswarapu, † S. Smith, † and K.-H. Grzeschik ${ }^{1}$ \\ Institut für Humangenetik, Bahnhofstr 7A, D-35037 Marburg, Germany; †HGMP Resource Centre, Harrow, Middlesex HA1 3UJ, \\ United Kingdom; and *Centre d'Etude du Polymorphisme Humain (CEPH), 27 rue Juliette Dodu, 75010 Paris, France
}

Received January 12, 1994; revised April 22, 1994

Disruption of the zinc finger gene GLI3 has been shown to be the cause of Greig cephalopolysyndactyly syndrome (GCPS), at least in some GCPS translocation patients. To characterize this genomic region on human chromosome $7 \mathrm{p} 13$, we have isolated a YAC contig of more than $1000 \mathrm{~kb}$ including the GLI3 gene. In this contig the gene itself spans at least $200-250 \mathrm{~kb}$. A CpG island is located in the vicinity of the 5 ' region of the known GLI3 cDNA, implying a potential promoter region. 1994 Academic Press, Inc.

\section{INTRODUCTION}

The Greig cephalopolysyndactyly syndrome (GCPS) is an autosomal dominant human malformation. The syndrome is characterized by preaxial polydactyly of the feet, postaxial polydactyly of the hands, syndactylies of hands and feet, and mild craniofacial abnormalities such as a slight hypertelorism and a high prominent forehead (Greig, 1926). The gene locus for GCPS has been pinpointed to human chromosome $7 \mathrm{p} 13$ by different translocations and deletions associated with the syndrome (Tommerup and Nielsen, 1983; Drabkin et al., 1989; Krüger et al., 1989; Pettigrew et al., 1991; Wagner et al., 1990). Using somatic cell hybrid lines from different GCPS translocation patients, we were able to localize the breakpoints to the same NotI restriction fragment (Vortkamp et al., 1991a). Later, we could show that the zinc finger gene GLI3 (Ruppert et al., 1988, 1990), which maps to the same genomic region, is disrupted by two of the GCPS translocations, while a third breakpoint is located $10 \mathrm{~kb}$ downstream of the expressed GLI3 gene sequence (Vortkamp et al., 1991b). These results suggested that a reduced expression of GLI3 is the cause of GCPS.

GLI3 belongs to the human GLI-Krüppel family of zinc finger genes and was originally isolated on the basis of its homology to GLI, which is amplified in some human glioblastomas. To characterize further the role

\footnotetext{
${ }^{1}$ To whom correspondence should be addressed. Telephone: 496421-284080. Fax: 49-6421-288920.
}

of the human GLI3 gene in developmental processes and to identify mutations in GCPS patients who do not show cytogenetic peculiarities, we are aiming at the complete genomic sequence of the gene. Preliminary mapping results indicated that the gene probably covers a large genomic region since the 5-kb GLI3 cDNA certainly corresponds to more than $80 \mathrm{~kb}$ of genomic DNA (Vortkamp et al., 1991b).

Therefore, to isolate the entire genomic GLI3 locus, we identified YAC clones from different libraries with probes from the gene region and anonymous markers that flank the GCPS translocation breakpoints. These YAC clones were ordered into a contig of about $1000 \mathrm{~kb}$ spanning the GLI3 gene and its surrounding genomic DNA. The integrity of the contig was controlled by PFGE analysis and hybridizations of end fragments to neighboring clones and to a somatic cell hybrid mapping panel.

\section{MATERIALS AND METHODS}

DNA probes and hybridization analysis. Probes p5-23, pFSA63, TG38, and CRI-R944 have been described previously (Donis-Keller et al., 1987; Rommens et al., 1988; Jobs et al., 1990; Vortkamp et al., 1991a). The GLI3 cDNA clone was kindly provided by $\mathbf{B}$. Vogelstein (Johns Hopkins University). GLI3prox is a 350-bp Not $\mathrm{I} /$ NcoI fragment containing the $5^{\prime}$ GLI3 cDNA, and GLI3dist is a $B g l \mathrm{IL} / E c o R V$ fragment of $3 \mathrm{~kb}$ from the 3 ' end of GLI3 (see Ruppert et al., 1990; and EMBL:HSGLI3A). For hybridization analysis, fragments were separated in LMP agarose gels, excised, and labeled directly by random priming (Feinberg and Vogelstein, 1984). All hybridizations were carried out under standard conditions (Church and Gilbert, 1984) for $16-18 \mathrm{~h}$ at $65^{\circ} \mathrm{C}$. Hybridization filters were washed with a final stringency of $50 \mathrm{~m} M \mathrm{Na} P_{\mathrm{i}}, 1 \% \mathrm{SDS}$ at $65^{\circ} \mathrm{C}$.

YAC library screening. YAC libraries were obtained as DNA pools from the Centre d'Etude du Polymorphisme Humain (CEPH; Albertsen et al., 1990), from the Imperial Cancer Research Fund (ICRF; Larin et al., 1991), and from the Human Genome Mapping Project Resource Center, Harrow (ICI library; Anand et al., 1990). These libraries were screened with primer pairs 5-23-19 (5'-CCTGGGAAGGTATTACTGC) and 5-23-20 (5'-GTGACTATGAATCATCAGCG) for probe p5-23 and GLIdistA (5'-TCTAATCTGCAGAATTACTC) and GLIdistE (5'-TGAAACAGATCTCAGTTAGG) for the $3^{\prime}$ part of the GLI3 gene (Vortkamp et al., 1991b; these primers amplify $580 \mathrm{bp}$ of the GLI3 cDNA and also the corresponding genomic DNA). Amplification conditions for both primer pairs were 40 cycles of $94^{\circ} \mathrm{C}$ for 30 $\mathrm{s}, 55^{\circ} \mathrm{C}$ for $30 \mathrm{~s}$, and $72^{\circ} \mathrm{C}$ for $1 \mathrm{~min}$ with an initial denaturation step of $94^{\circ} \mathrm{C}$ for $5 \mathrm{~min}$ and a final extension step of $72^{\circ} \mathrm{C}$ for $10 \mathrm{~min}$. PCR 
products (approx. $550 \mathrm{bp}$ for $5-23 ; 589 \mathrm{bp}$ for GLIdist) were analyzed by agarose gel electrophoresis. Direct screening of the ICI library was carried out by hybridization of gridded YAC library filters with probe GLI3prox

YAC DNA analysis. Single YAC colonies were inoculated into 100 $\mathrm{ml} \mathrm{AHC}$ medium and grown for $48 \mathrm{~h}$ at $30^{\circ} \mathrm{C}$. One-half of the culture was used for liquid DNA isolation and the other for the preparation of agarose-embedded DNA according to standard methods (Ausubel et al., 1993). For Southern blot analysis yeast DNA was digested with EcoRI, separated in $0.8 \%$ agarose gels, and transferred to Hybond N filters. For PFGE analysis DNA was digested in agarose blocks with $20 \mathrm{U} B s s \mathrm{HII}, N o t \mathrm{I}$, or MluI for $3 \mathrm{~h}$. PFGE was carried out in a LKB hexagonal electrophoresis system with $1 \%$ agarose gels at $200 \mathrm{~V}$ and pulse ramping from 1 to $40 \mathrm{~s}$ for $24 \mathrm{~h}$ at $12^{\circ} \mathrm{C}$. DNA was blotted by alkaline transfer.

YAC end fragment PCR. The procedure given by Kere et al. (1992) was followed throughout. In brief, $0.2-1 \mu \mathrm{g}$ of YAC DNA was digested with $R s a \mathrm{I}$ or $P v u \mathrm{II}$ and $S c a \mathrm{I}$ for $1 \mathrm{~h}$ at $37^{\circ} \mathrm{C}$. After heat inactivation of restriction enzymes at $68^{\circ} \mathrm{C}$ for $15 \mathrm{~min}$, the double-stranded linker LIS1 +2 was ligated for $2 \mathrm{~h}$ at RT. The first PCR amplification, carried out with primer mix UR + LIS1 or UL + LIS1, was followed by a second round of PCR with primer mixes RA2 + LIS1 or LS2 + LIS1. PCR products were separated on $0.8 \%$ LMP-agarose and cut out for radioactive labeling. Primers UR and RA2 correspond to the YAC arm detected by the 1.69-kb PvuIL/Bam HI fragment of pBR322, which is also frequently referred to as the right arm of a YAC clone.

Cell hybrid mapping panel. The chromosome $7 \mathrm{p}$-specific hybrid panel contained cell lines GM3160, 5387-3 cl 10, 1356 Rag 12-9, RoH Rag 9-32, Ru Rag 4-13, and Rag (Vortkamp et al., 1991a). The DNAs were digested with $E$ coRI, and Southern blot analysis was carried out as described for the YAC DNAs.

\section{RESULTS}

\section{Isolation of YAC Clones}

In a PCR-based approach we screened pools of the $\mathrm{CEPH}$, ICRF, and ICI YAC libraries (Anand et al., 1990; Albertsen et al., 1990; Larin et al., 1991) using primers from the distal part of GLI3 and the flanking probe p5-23. The latter probe defines the $\mathrm{CpG}$ island on the telomeric side of a $550-\mathrm{kb}$ Not I fragment that is detected by the GLI3 cDNA. Screening of 113 pools (43,400 clones) of the CEPH library with the p5-23 primers identified two positive clones, y5-23A (72B1) and y5-23B (406E4), whereas no GLI3 YAC could be detected in this library. Similarly, screening the CEPHII and ICRF libraries identified no GLI3 containing YAC clones with the primer pair from the gene. PCR screening of the pooled ICI YAC library (34,560 clones), however, resulted in six positive YACs, $12 \mathrm{FG} 1$, 19AE4, 20AD5, 29FD11, 32ID9, and 32ID10 for GLI3. Initial experiments suggested that these clones may not extend very far on the $5^{\prime}$ end of the GLI3 cDNA. Therefore, duplicate filters containing gridded YAC DNA of the ICI library were hybridized with a $5^{\prime}$ cDNA probe (GLIprox). Two additional YACs, 7DF5 and $22 \mathrm{BE} 7$, were identified in this way.

\section{Estimation of YAC Overlap}

To identify overlaps between individual clones, $E$ coRI-digested YAC DNA was hybridized with markers from the GLI3 gene region. These hybridizations (Fig.

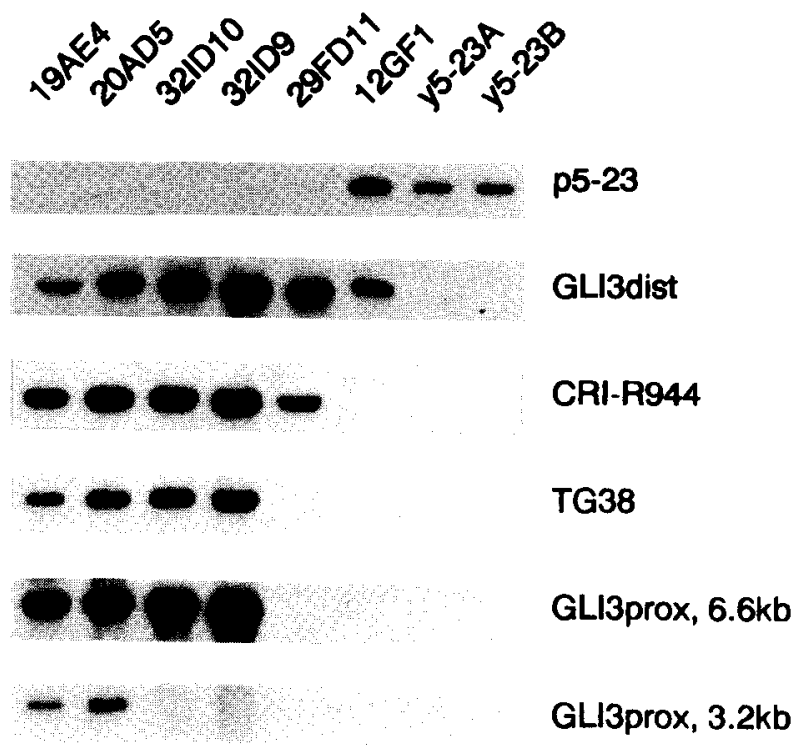

FIG. 1. The isolated YACs contain different parts of the GLI3 gene region. Southern blots with EcoRI-digested DNA of the isolated YAC clones were hybridized with probes from chromosome $7 \mathrm{p} 13$ flanking the GCPS translocation breakpoints as listed to the right. Probe p5-23 is the most telomeric probe contained in the contig, whereas the 3.2-kb EcoRI fragment detected by the 5' part of the GLI3 cDNA defines the centromeric side of the gene.

1) showed that the YACs overlap and cover the GLI3 region. Most important, YAC 12FG1 hybridizes with probes p5-23 and GLI3dist, thus connecting the CEPH YACs for the p5-23 locus with GLI3 YACs identified in the ICI library and establishing a continuously cloned DNA segment. After the initial screening of the ICI library by PCR, YACs $19 \mathrm{AE} 4$ and 20AD5 seemed to include the most proximal part of the gene. These YACs, however, appeared to be rearranged with one end of each clone not being derived from chromosome 7 (see below). The subsequent hybridization screening identified a third clone, 22BE7, that contains the proximal part of the gene without any sign of rearrangement. Hybridization of the YACs with probes TG38 and CRI-R944, previously localized centromeric to the GCPS translocation breakpoints, revealed that these probes map within the GLI3 gene region. No evidence for internal deletions of the YAC isolates could be detected in these hybridization studies. In parallel experiments (data not shown), the overlap between the contig clones has also been verified by comparing $\mathrm{Alu}$ PCR fingerprints generated with primers CL1, CL2, and CL1/CL2 in combination (Lengauer et al., 1992).

\section{PFGE Analysis}

The size of the individual YACs was determined after hybridization of PFGE-separated YAC DNA with total human DNA. The YACs derived from the CEPH library are 420 and $575 \mathrm{~kb}$ long, respectively, whereas the ICI YACs have an average size of $300-400 \mathrm{~kb}$. There was one very short clone of $160 \mathrm{~kb}$ (7DF5), while the two 

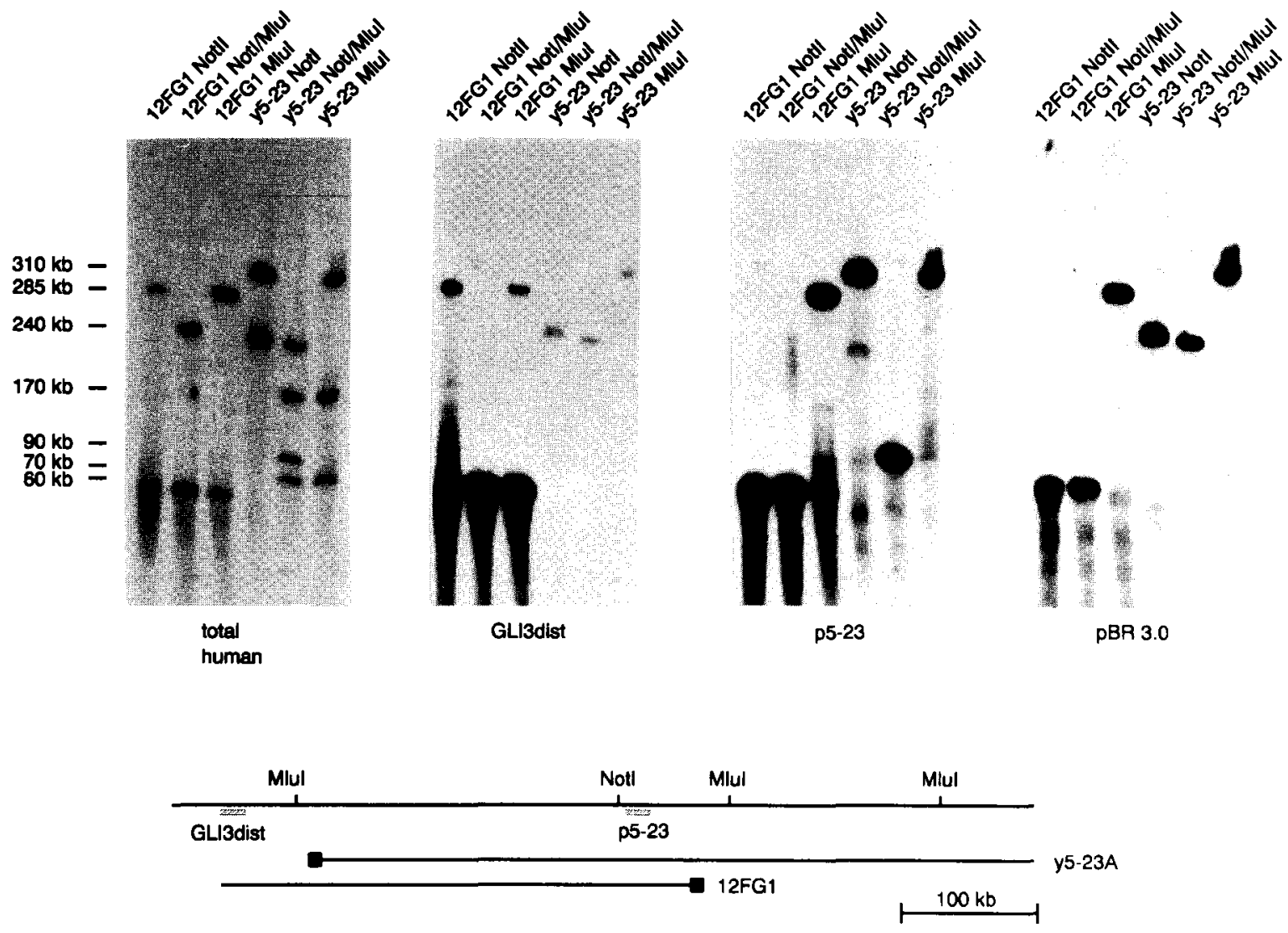

FIG. 2. PFGE analysis of YAC clones $12 \mathrm{FG} 1$ and y5-23A (72B1). A Southern blot filter containing YAC DNA digested with different rare-cutter enzymes was successively hybridized with total human DNA, markers from the gene region, and YAC arm-specific fragments of pBR322. The resulting map is shown in the lower part of the figure. pBR 3.0, a 2.67-kb BamHI/PvuII fragment of pBR322, detects the left arm of the YAC vector, which is marked by a filled square in the PFGE map.

rearranged clones, $19 \mathrm{AD} 4$ and $20 \mathrm{AD} 5$, were more than $700 \mathrm{~kb}$ in size.

A detailed map of the chromosomal region has been established by restriction mapping of YAC DNAs with the rare-cutting enzymes $N o t \mathrm{I}, B s s \mathrm{HII}$, and $M l u \mathrm{I}$ followed by successive hybridizations with GLI3 cDNA probes, other markers from the GLI3 region and YAC vector-specific fragments of $\mathrm{pBR} 322$. An example of such a hybridization is shown in Fig. 2. The YAC contig finally deduced from PFGE mapping in combination with the hybridization data of Fig. 1 spans more than $1000 \mathrm{~kb}$ of genomic DNA (Fig. 3). The GLI3 gene appears to be spread over a region of about $250 \mathrm{~kb}$. The $5^{\prime}$ end of the cloned GLI3 cDNA is located close to a CpG island defined by NotI, BssHII, and KspI (not shown) restriction sites, and this island may well be a candidate for the promotor region of GLI3. Probe p523 is located $260 \mathrm{~kb}$ telomeric to the GLI3 gene, whereas the other anonymous DNA markers, TG38, CRI-R944, and pFSA63, are located within the GLI3 gene.

\section{Integrity of the Contig}

To verify the integrity of individual YAC inserts and to confirm overlaps between different clones, we ampli- fied the end fragments of YAC inserts by PCR and hybridized these to $E c o$ RI-digested DNA of all YAC clones contained in the contig. In addition, the proximal and distal ends of the contig as well as some of the internal YAC end fragments were mapped back to chromosome 7 p13 using a somatic cell hybrid panel (Table 1).

YAC insert ends were amplified by a two-stage linker PCR as described by Kere et al. (1992), resulting in PCR products in the range of $200-1500$ bp that were used directly as hybridization probes. Of 16 YAC end fragments, 14 could be isolated and hybridized to Southern blots. The remaining two YAC ends have also been amplified, but the isolated DNA fragments were less than $200 \mathrm{bp}$ in size and did not give a hybridization signal. On the centromeric side of the PFGE, the end fragment of YAC 19AE4 did not hybridize with human chromosome 7, suggesting that the insert resulted from a coligation of unrelated fragments. The next most proximal end fragment of the contig, however, derived from clone $22 \mathrm{BE} 7$, correctly mapped to chromosome 7p13. This fragment also hybridizes with clone 19AE4, implying that the rearrangement in $19 \mathrm{AE} 4$ occurred proximal to the end of $22 \mathrm{BE} 7$. The most telomeric end fragment of our contig, amplified from clone y5-23B (406E4), could also be localized on chromosome $7 \mathrm{p}$. 


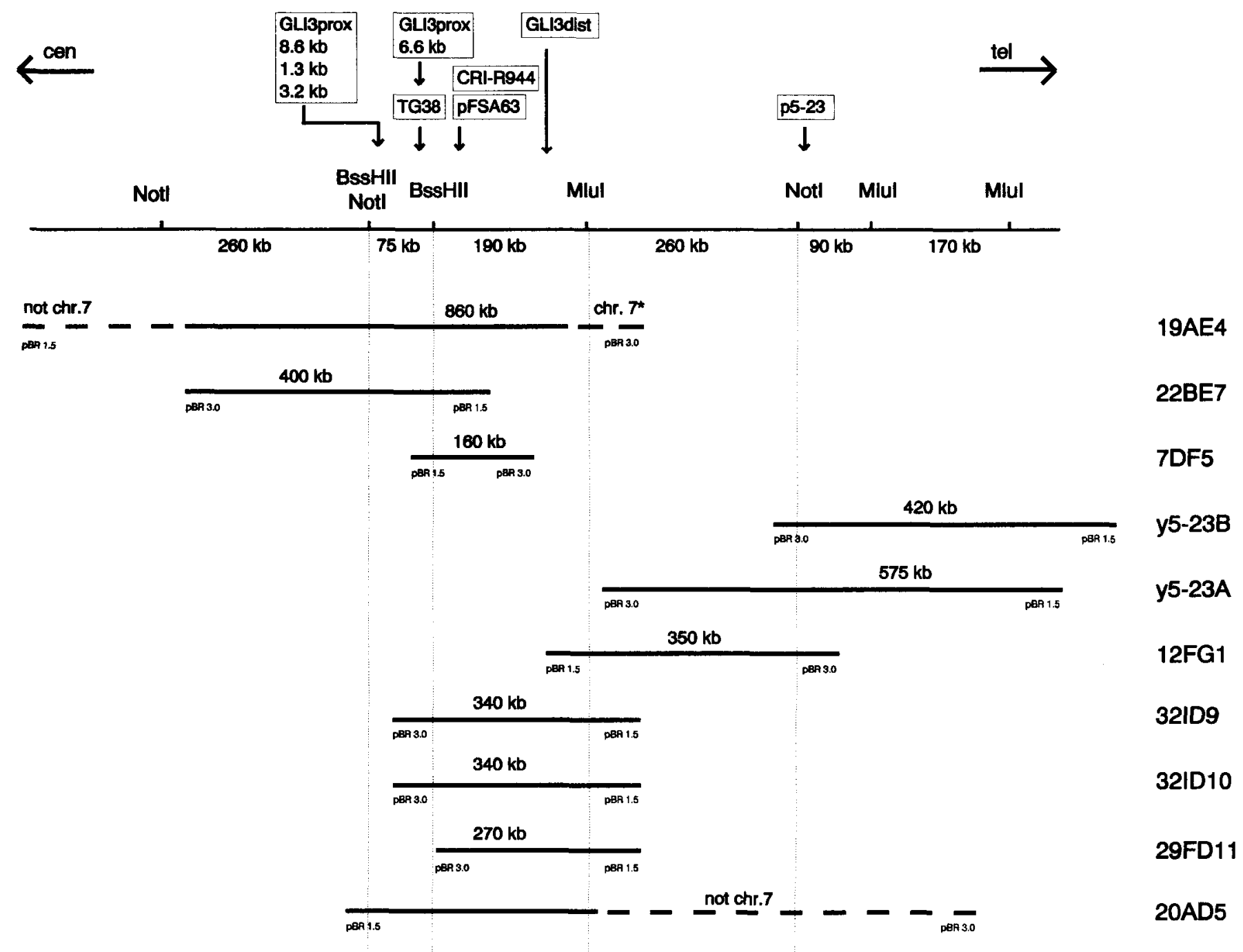

FIG. 3. A PFGE map of the YAC contig linking the GLI3 gene with markers from chromosome 7p13. The GLI3 gene spans a genomic region of $250 \mathrm{~kb}$ with the $5^{\prime}$ end located close to a $\mathrm{CpG}$ island. Probes used for hybridization are shown in boxes, and arrows point to the map regions at which these probes are located. The proximal $350 \mathrm{bp}$ of the cloned GLI3 cDNA (probe GLI3prox) detects four different EcoRI restriction fragments that are spread over $75 \mathrm{~kb}$. YACs without any sign of rearrangement are displayed as solid bars, whereas rearranged parts of YACs are marked by dashed lines. The lengths of the individual YACs are indicated above the bars. pBR 3.0 indicates the left vector arm, pBR1.5 the right arm. Chr $7^{*}$ marks the telomeric end of clone 19AE4, which maps back to some of the YAC clones, but gives inconsistent results (see text).

Mapping of the internal end fragments to the YACs of the contig gave consistent results in almost all cases. Only the telomeric end of 19AE4 does not fit into the PFGE map. Since this clone is missing the MluI site that is present in all other clones, it appears likely that clone 19AE4 is also rearranged at its telomeric end. YAC 20AD5 has not yet been fully characterized, but it seems to be rearranged downstream of the GLI3 gene (Fig. 3).

All other YAC end fragments gave hybridization patterns with the other clones that agree well with the results of the PFGE mapping. In addition to the end fragments of the contig (22BE7 and y5-23B (406E4)), internal YAC end fragments of clones 32ID10 and 29FD11 are located on human chromosome 7p13. Thus, the isolated contig spans at least $1050 \mathrm{~kb}$ of the GLI3 gene region. The majority of the clones seem to be faithful copies of human DNA segments with no internal deletions or rearrangements.

\section{DISCUSSION}

The molecular analysis of GLI3 alterations in GCPS patients requires a detailed map for the gene to be established and the genomic DNA to be cloned. Since previous data suggested a large size for the genomic GLI3 region, we isolated YAC clones for GLI3 and the flanking marker p5-23 from the CEPH, ICRF, and ICI libraries. By PCR-based screening approaches and hybridization of filters with gridded YAC clones (ICI library), we have identified 10 YAC clones that span more than $1000 \mathrm{~kb}$ of genomic DNA. Of these, 2 clones, 
TABLE 1

Mapping of YAC Ends to Contig Clones and a Chromosome 7 Hybrid Panel

\begin{tabular}{|c|c|c|c|c|c|c|c|c|c|c|}
\hline & & End & $\mathrm{Chr}$ & $19 \mathrm{AE} 4$ & 32ID9 & $32 \mathrm{ID} 10$ & 29FD11 & $12 \mathrm{FG} 1$ & $5-23 \mathrm{~A}$ & $5-23 B$ \\
\hline \multirow[t]{2}{*}{1} & 19AE4-R & Tel & $7 \mathrm{p} 13$ & + & + & + & + & - & - & - \\
\hline & 19AE4-L & Cen & Not 7 & + & - & - & - & - & - & - \\
\hline \multirow[t]{2}{*}{2} & 22BE7-gc35 & Tel & $7 \mathrm{p} 13$ & + & + & + & + & - & - & - \\
\hline & $22 \mathrm{BE} 7-\mathrm{gc} 57$ & Cen & $7 \mathrm{p} 13$ & + & - & - & - & - & - & - \\
\hline \multirow[t]{2}{*}{3} & 7DF5-R & Cen & & + & + & + & - & - & - & - \\
\hline & 7DF5-L & $\mathrm{Tel}$ & & + & + & + & + & - & - & - \\
\hline \multirow[t]{2}{*}{4} & 32ID9-R & Tel & & - & + & + & - & + & + & - \\
\hline & 32ID9-L & Cen & & + & + & + & - & - & - & - \\
\hline \multirow[t]{2}{*}{5} & $32 \mathrm{ID} 10-\mathrm{R}$ & $\mathrm{Tel}$ & $7 \mathrm{p} 13$ & - & + & + & - & + & + & - \\
\hline & 32ID10-L & Cen & $7 \mathrm{p} 13$ & + & + & + & - & - & - & - \\
\hline \multirow[t]{2}{*}{6} & 29FD11-R & $\mathrm{Tel}$ & $7 \mathrm{p} 13$ & - & + & + & + & + & + & - \\
\hline & 29FD11-L & Cen & & + & + & + & + & - & - & - \\
\hline \multirow[t]{2}{*}{7} & 12FG1-R & Cen & & + & + & + & + & + & - & - \\
\hline & 12FG1-L & Tel & & - & - & - & - & + & + & + \\
\hline 8 & 5-23A-L (72B1) & Cen & & - & + & + & + & + & + & - \\
\hline 9 & 5-23B-R $(406 \mathrm{E} 4)$ & $\mathrm{Tel}$ & $7 \mathrm{p} 13$ & - & - & - & - & - & - & + \\
\hline
\end{tabular}

Note. Hybridization results of PCR-amplified YAC ends with EcoRI-digested YAC DNA and the chromosome 7-specific hybrid panel. For 22BE7 the hybridization was carried out with cosmid fragments corresponding to the ends of the YAC clone (manuscript in preparation).

19AE4 and 20AD5, appeared to be rearranged after further analysis. This was not unexpected since the insert sizes of these clones were more than twice the average size of the ICI library. The other 8 YAC clones showed no sign of deletion or rearrangement. This compares favorably with results from other regions of the human genome where much higher numbers of rearranged clones have been detected (Bates et al., 1992) and corroborates the previous observation that the coligation frequency in the ICI YAC library is low (less than 10\%) when compared to other human genomic YAC libraries (R. Anand, ICI Pharmaceuticals, UK, pers. commun., 1992). The absence of GLI3 sequences in the ICRF and CEPH I + II libraries, however, and the fact that none of the faithful clones includes the entire GLI3 gene, suggest that there may nevertheless be sequences in the GLI3 region that are not easily clonable.

All YAC clones were tested for the presence of different markers or gene fragments, and their PFGE restriction maps were established. Combining these data with results from $A l u-\mathrm{PCR}$ and YAC end fragment mapping led to a final ordered contig of $1050 \mathrm{~kb}$ of DNA faithfully derived from chromosome $7 \mathrm{p} 13$. Although none of the unrearranged clones contained the entire GLI3 gene, the density of YACs was high enough to cover the chromosomal GLI3 region. In the isolated contig the currently available GLI3 cDNA spans a genomic region of approximately $250 \mathrm{~kb}$. The large size of the gene is consistent with prior results, as two $\lambda$ phage contigs of 30 and $50 \mathrm{~kb}$ that have been isolated for the proximal and distal ends of the cDNA did not overlap (Vortkamp et al., 1991b).

The $5^{\prime}$ end of the cloned cDNA is located near a CpG island (Fig. 3) that may mark promoter elements. It is, nevertheless, possible that the GLI3 promoter is located at some distance from this site since Northern blot analysis suggested an approximately $3.5-\mathrm{kb}$ noncoding $5^{\prime}$ region in the mRNA (Ruppert et al., 1990) that is not contained in the cDNA clones available. Isolation of a mouse Gli3 cDNA clone that reaches 500 bp farther upstream (Vortkamp et al., 1992) supports this idea. Additional evidence is derived from the analysis of the homologous mouse mutation "anterior digit deformity" (add) that resulted from the integration of a transgene (Pohl et al., 1990). The expression level of Gli3 is reduced in these mutants and the transgene integration site has been mapped approximately $40 \mathrm{~kb}$ upstream of the coding start of GLI3. Thus, it appears that the GLI3 $5^{\prime}$ region is spread over a large region or else the expression of the gene can be controlled over long distances. Any cloned DNA upstream of the currently known GLI3 cDNA will facilitate experiments aimed at the characterization of this part of the GLI3 gene: the identification of promotor elements and the cloning of the remaining GLI3 cDNA by direct selection techniques, as this cDNA part appears to be difficult to clone using different libraries (unpublished results).

The YAC contig isolated in this study also provides a valuable resource for the identification of the GCPS translocation breakpoints and the screening in GCPS patients for yet uncharacterized GLI3 alterations. The subcloning of distinct YACs into cosmids to analyze the fine structure of the GLI3 gene is well under way. GLI3 exons as well as the GCPS translocation breakpoints can then be located on discrete restriction fragments and subsequently their sequence can be determined to derive primers for mutation screening.

The availability of large genomic segments encoding GLI3 with its regulatory domains will permit direct testing of the homology between the human GCPS and the mouse mutations extra toes (Xt) (Johnson, 1967; Winter and Huson, 1988) and add in transgenic ani- 
mals. Unlike add, the Xt phenotype results from a large deletion that includes the 5' region of GLI3 (Vortkamp et al., 1992). Since GCPS and Xt are likely to be caused by haploinsufficiency of GLI3, precise dosage control seems to be required during limb development, and reconstitution experiments in Xt mice will similarly need authentic promoter elements. Such a system will finally allow one to introduce defined alterations in regulatory regions or the gene itself to study individual components.

\section{ACKNOWLEDGMENTS}

We thank Bert Vogelstein for providing the GLI3 cDNA clone and $\mathrm{H}$. Lehrach and M. Ross for sending DNA pools of the ICRF YAC library. Bärbel Schulz and Christiane Heid provided excellent technical assistance. This work was supported by the Deutsche Forschungsgemeinschaft.

\section{REFERENCES}

Albertsen, H. M., Abderrahin, H. M., Cann, H. M., Dausset, J., Le Paslier, D., and Cohen, D. (1990). Construction and characterization of a yeast artificial chromosome library containing seven haploid human genome equivalents. Proc. Natl. Acad. Sci. USA 87: 4256-4260.

Anand, R., Riley, J. H., Butler, R., Smith, J. C., and Markham, A. F. (1990). A 3.5 genome equivalent multi access YAC library: Construction, characterization, screening and storage. Nucleic Acids Res. 18: 1951-1956.

Ausubel, F. M., Brent, R., Kingston, R. E., Moore, D. D., Seidman, J. G., Smith, J. A., and Struhl, K. (1993). "Current Protocols in Molecular Biology," Greene Publishing and Wiley-Interscience, New York.

Bates, G. P., Valdes, J., Hummerich, H., Baxendale, S., Le Paslier, D. L., Monaco, A. P., Tagle, D., MacDonald, M. E., Altherr, M., Ross, M., Brownstein, B. H., Bentley, D., Wasmuth, J. J., Gusella, J. F., Cohen, D., Collins, F., and Lehrach, H. (1992). Characterization of a yeast artificial chromosome contig spanning the Huntington's disease gene candidate region. Nature Genet. 1: 180-187.

Church, G. M., and Gilbert, W. (1984). Genomic sequencing. Proc. Natl. Acad. Sci. USA 81: 1991-1995.

Donis-Keller, H., Green, P., Helms, C., Cartinhour, S., Weiffenbach, B., Stephens, K., Keith, T. P., Bowden, D. W., Smith, D. R., Lander, E. S., Botstein, D., Akots, G., Rediker, K. S., Gravius, T., Brown, V. A., Rising, M. B., Parker, C., Powers, J. A., Watt, D. E., Kauffman, E. R., Bricker, A., Phipps, P., Muller-Kahle, H., Fulton, T. R., Ng, S., Schumm, J. W., Braman, J. C., Knowlton, R. G., Barker, D. F., Crooks, S. M., Lincoln, S. E., Daily, M. J., and Abrahamson, J. (1987). A genetic linkage map of the human genome. Cell 51: $319-337$.

Drabkin, H., Sage, M., Helms, C., Green, P., Gemmill, R., Smith, D., Erickson, P., Hart, I., Ferguson-Smith, A., Ruddle, F., and Tommerup, N. (1989). Regional and physical mapping studies characterizing the Greig polysyndactyly $3 ; 7$ chromosome translocation (3;7)(p21.1;p13). Genomics 4: 518-529.

Feinberg, A. P., and Vogelstein, B. (1984). A technique for radiolabelling DNA restriction endonuclease fragments to high specific activity. Addendum. Anal. Biochem. 137: 266-267.

Greig, D. M. (1926). Oxycephaly. Edinburgh Med. J. 33: 189-218.

Jobs, A., Klein-Bölting, D., Jandel, A. S., Driesel, A., Olek, K., and Grzeschik, K. H. (1990). Regional assignment of 41 human DNA fragments on chromosome 7 by means of a somatic cell hybrid panel. Hum. Genet. 84: 147-150.
Johnson, D. R. (1967). Extra-toes: A new mutant gene causing multiple abnormalities in the mouse. J. Embryol. Exp. Morphol. 17: $543-581$.

Kere, J. M., Nagaraja, R., Mumm, S., Ciccodicola, A., Durso, M., and Schlessinger, D. (1992). Mapping human chromosomes by walking with sequence-tagged sites from end fragments of yeast artificial chromosome inserts. Genomics 14: 241-248.

Krüger, G., Götz, J., Kvist, U., Dunker, H., Erfurth, F., Pelz, L., and Zech, L. (1989). Greig syndrome in a large kindred due to reciprocal chromosome translocation $\mathrm{t}(6 ; 7)(\mathrm{q} 27 ; \mathrm{p} 13)$. Am. J. Med. Genet. 32: 411-416.

Larin, Z., Monaco, A. P., and Lehrach, H. (1991). Yeast artificial chromosome libraries containing large inserts from mouse and human DNA. Proc. Natl. Acad. Sci. USA 88: 4123-4127.

Lengauer, C., Green, E. D., and Cremer, T. (1992). Fluorescence in situ hybridization of YAC clones after Alu-PCR amplification. Genomics 13: 826-828.

Pettigrew, A. L., Greenberg, F., Caskey, C. T., and Ledbetter, D. H. (1991). Greig syndrome associated with an interstitial deletion of $7 \mathrm{p}$ : Confirmation of the localization of Greig syndrome to $7 \mathrm{p} 13$. Hum. Genet. 87: 452-456.

Pohl, T. M., Mattei, M. G., and Rüther, U. (1990). Evidence for allelism of the recessive insertional mutation add and the dominant mouse mutation extra-toes (Xt). Development 110: 1153-1157.

Rommens, J. M., Zengerling, S., Burns, J., Melmer, G., Kerem, B.-S., Plavsic, N., Zsiga, M., Kennedy, D., Markiewicz, D., Rozmahel, R., Riordan, J. R., Buchwald, M., and Tsui, L.-C. (1988). Identification and regional localization of DNA markers on chromosome 7 for the cloning of the cystic fibrosis gene. Am. J. Hum. Genet. 43: $645-663$.

Ruppert, J. M., Kinzler, K. W., Wong, A. J., Bigner, S. H., Kao, F.-T., Law, M. L., Seuanez, H. N., O'Brien, S. J., and Vogelstein, B. (1988). The GLI-Krüppel family of human genes. Mol. Cell. Biol. 8: $3104-3113$.

Ruppert, J. M., Vogelstein, B., Arheden, K., and Kinzler, K. W. (1990). GLI3 encodes a 190-kilodalton protein with multiple regions of GLI similarity. Mol. Cell. Biol. 10: 5408-5415.

Sambrook, J., Fritsch, E. F., and Maniatis, T. (1989). "Molecular Cloning: A Laboratory Manual," Cold Spring Harbor Laboratory Press, Cold Spring Harbor, NY.

Tommerup, N., and Nielsen, F. (1983). A familial reciprocal translocation $\mathrm{t}(3 ; 7)(\mathrm{p} 21.1 ; \mathrm{p} 13)$ associated with the Greig polysyndactylycraniofacial anomalies syndrome. Am. J. Med. Genet. 16: 313-321.

van der Hoeven, F., Schimmang, T., Vortkamp, A., and Rüther, U. (1993). Molecular linkage of the morphogenetic mutation $a d d$ and the zinc finger gene Gli3. Mamm. Genome 4: 276-277.

Vortkamp, A., Thias, U., Gessler, M., Rosenkranz, W., Kroisel, P. M., Tommerup, N., Krüger, G., Götz, J., Pelz, L., and Grzeschik, K.-H. (1991a). A somatic cell hybrid panel and DNA probes for physical mapping of human chromosome 7p. Genomics 11: 737743.

Vortkamp, A., Gessler, M., and Grzeschik, K.-H. (1991b). GLI3 zinc finger gene interrupted by translocations in Greig syndrome families. Nature 352: 539-540.

Vortkamp, A., Franz, T., Gessler, M., and Grzeschik, K.-H. (1992). Deletion of $G L I 3$ supports the homology of the human Greig cephalopolysyndactyly syndrome (GCPS) and the mouse mutant extra toes $(X t)$. Mamm. Genome 3: 461-463.

Wagner, K., Kroisel, P. M., and Rosenkranz, W. (1990). Molecular and cytogenetic analysis in two patients with microdeletions of $7 p$ and Greig syndrome: Hemizygosity for PGAM2 and TCRG genes. Genomics 8: 487-491.

Winter, R. M., and Huson, S. M. (1988). Greig cephalopolysyndactyly syndrome: A possible mouse homologue (Xt-extra toes). Am. J. Med. Genet. 31: 793-798. 